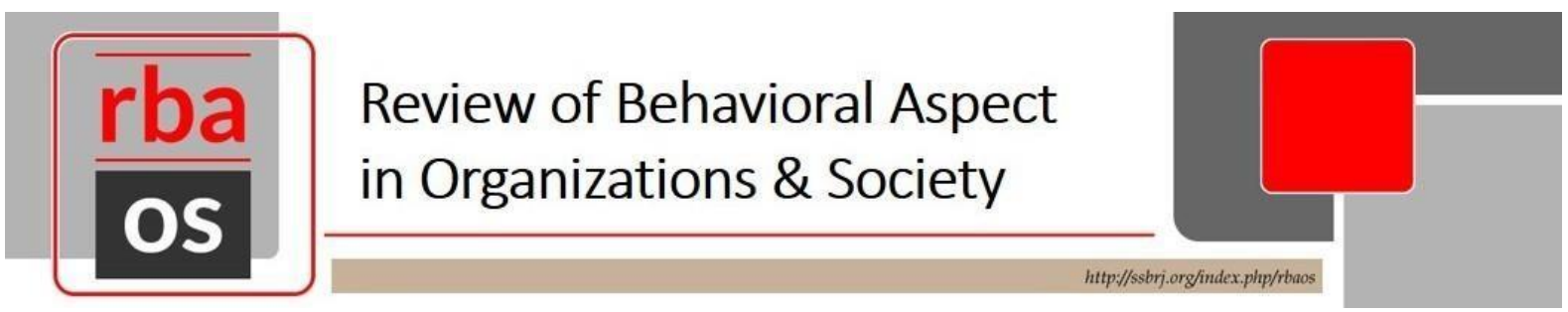

Vol 3 (1), 2021, 35-44

\title{
THE INFLUENCE OF MANAGEMENT ACCOUNTABILITY OF VILLAGE FUND ALLOCATION ON COMMUNITY WELFARE IN CIBODAS VILLAGE
}

\author{
Lilis Saidah Napisah, STIE Ekuitas Bandung, Indonesia ${ }^{1}$ \\ Vania Rakhmadhani, STIE Ekuitas Bandung, Indonesia ${ }^{2}$
}

\begin{abstract}
This study aims to determine how much influence the management accountability of village fund allocation affects community welfare in Cibodas village, Solokan Jeruk district, Bandung regency. The independent variable in this study is the management accountability of village fund allocation, while the dependent variable is community welfare. The method used in this research is the descriptive quantitative method. The population in this study was the Cibodas village community. The method used in determining the sample was the purposive sampling method. The data in this study were collected through a questionnaire analyzed using simple linear regression analysis. This study shows that the management accountability of village fund allocation influences the community welfare in Cibodas village, Solokan Jeruk district, Bandung regency.
\end{abstract}

Keywords: Management accountability of village fund allocation; Community welfare

\section{Introduction}

Based on Law Number 11 of 2009 concerning Social Welfare, community welfare is a condition for the fulfilment of citizens' material, spiritual, and social needs to live correctly and develop themselves so that they can perform their social activities and functions. According to Statistics Indonesia, the level of public welfare in 2017 was studied in eight areas, i.e. population, health and nutrition, education, employment, consumption levels and patterns, housing and environment, poverty, and other social references to improve the quality of life.

The Regulation of the Minister of Internal Affairs of the Republic of Indonesia, Number 114 of 2014 concerning Guidelines for Village Development, states that "Village fund allocation, after this abbreviated as ADD, is a balanced fund received by districts/cities in the district/city Regional Revenue and Expenditure Budget after deducting the Special Allocation Fund." Since the initial allocation of village funds, the budget for village funds has always increased. This increase in the village fund allocation has a positive impact on villages and village communities, some of which include better village infrastructure such as providing health posts for rural communities, building road construction, and other infrastructure. However, the existence of a large village budget can create serious problems. If not accompanied by the ability to manage finances properly and correctly, these problems will arise. 
Each year, the amount of the State Revenue and Expenditure Budget (APBN) transferred to village funds tends to continue to increase.

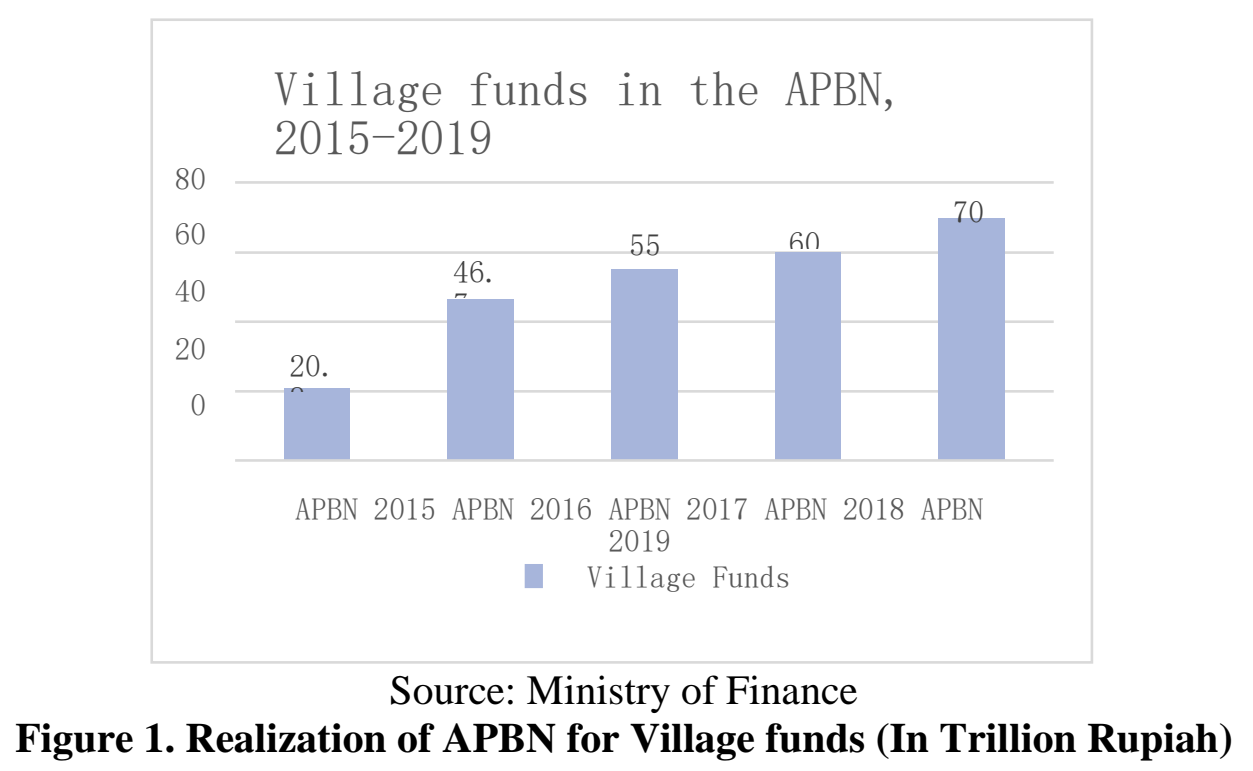

With the increase in the village fund budget every year, it is hoped that the management of these funds will be excellent, both in infrastructure development and community welfare. There is also accountability by reporting and disclosing all activities related to allocating these funds to the community.

The main problem of a large village budget is corruption committed by village fund managers, i.e., village officials and even village heads who commit village funds corruption. Based on the monitoring results conducted by the Indonesian Corruption Watch (ICW) from 2015 to 2019 , cases of corruption in village funds have continued to increase from one year to another. In 2015, there were 22 cases of corruption, and in 2016 it increased to 48 cases; in 2017, there were 98 cases; in 2018, there were 96 cases; and in 2019, there were the most cases of corruption with 271 cases that caused the state loss of Rp. 32.2 billion.

With the many problems that arise from the significant allocation of village funds, Minister of Internal Affairs Regulation Number 20 of 2018 concerning Village Financial Management states that village finances are managed using transparent, accountable, participatory principles and carried out in an orderly and disciplined budget. The four principles are formulated to minimize fraud in extensive village financial management.

There are still many villages whose infrastructure development is still lacking, such as Cibodas Village, Solokan Jeruk District, Bandung Regency. The condition of road infrastructure in Cibodas Village, Solokan Jeruk District is worrying; its condition is damaged and has many holes. From the above problems, it is necessary to allocate village funds that are open and accountable to create a comprehensive village community welfare.

\section{Research Formulation}

Based on the background description above, the problem formulations in this study are as follows:

1. What are the descriptions for village fund allocation management accountability and the community welfare in Cibodas village?

2. How does village fund allocation management accountability influence the community welfare in Cibodas village? 


\section{Literature Review}

\section{Village Fund}

Village funds based on Government Regulation Number 60 of 2014 are managed in an orderly manner, obeying laws and regulations, efficient, economical, effective, transparent, and responsible by paying attention to the sense of justice and appropriateness and prioritizing the interests of the local community. According to Government Regulation Number 60 of 2014, the definition of village funds is funds sourced from the State Revenue and Expenditure Budget (APBN) intended for villages. Village funds are transferred through the district/city Regional Revenue and Expenditure Budget (APBD) and are used to finance government administration, implementation of development, community development, and community empowerment. Every year, the government budgeted village funds nationally in the State Revenue and Expenditure Budget (APBN). The village funds come from government spending by making village-based programs evenly and equitably effective.

\section{Village Financial Management}

Several principles must be used as guidelines to achieve effectiveness and efficiency in village financial management. This principle of village financial management is explained in the Minister of Internal Affairs Regulation Number 20 of 2018 concerning Village Financial Management. In the article, village finances are managed based on the following principles:

1. Transparency - the principle of openness that allows the community to know and get the widest possible access to information about village finances.

2. Accountable - the embodiment of the obligation to take responsibility for those entrusted to achieve the set goals.

3. Participatory - the implementation of village governance that includes village institutions and elements of village society.

4. Budgetary order and discipline-village financial management must refer to the underlying rules or guidelines.

\section{Accountability}

With accountability, the performance of the village government in carrying out its duties and functions will be measured, such as in managing funds, compiled work programs, and other determined policies. According to (Mardiasmo,2015), accountability is an obligation to report and be responsible for the success or failure of the organization's mission in achieving predetermined results. It can be done through accountability media which is carried out regularly. Accountability consists of two types, i.e., vertical accountability and horizontal accountability. In general, vertical accountability is the accountability between superior and subordinate relationships or in government studies, means accountability to the central government. Meanwhile, horizontal accountability is accountability in horizontal form, i.e., to the community. Accountability is the duty of the agent (government) to manage resources, report, and disclose all activities related to the use of public resources to the mandate (principal) (Mahmudi,2016).

\section{Public Welfare}

In-Law Number 11 of 2009 concerning Social Welfare, community welfare is a condition for the fulfillment of citizens' material, spiritual and social needs to live properly and develop themselves so that they can perform their social functions.

The level of community welfare, according to Statistics Indonesia in 2017, is assessed according to the following eight areas: 
1. Population

2. Health and nutrition

3. Education

4. Employment

5. Levels and patterns of consumption

6. Housing and environment

7. Poverty

8. As well as other social references in efforts to improve the quality of life.

\section{Method}

The method used in this research is the descriptive method. The variables used in this study are the management accountability of village fund allocation and community welfare. These variables are grouped into 2, i.e. the independent variable in this study is the management accountability of village fund allocation $(\mathrm{X})$, and the dependent variable in this study is the community welfare (Y). The data source used in this research is primary data. The instrument used in this study was a questionnaire distributed to the people of Cibodas village, Solokan Jeruk district, Bandung regency who already have voting rights and/or are 17 years of age and over.

\section{Data analysis}

The analysis technique used in this research is a descriptive analysis using the SPSS 22 application software. The purpose of descriptive analysis using these statistics is to interpret respondents' arguments against the choice of statements and the frequency distribution of respondents' statements based on the collected data. The data analyses used were as follows:

\section{Validity Test}

The validity test is used when testing whether a questionnaire is valid or not. A questionnaire is said to be valid if the statement on the questionnaire can reveal something that will be measured by the questionnaire and has a validity coefficient greater than the specified critical value (Ghozali, 2018). In implementing this validity test, it is carried out by correlating Item Correlation by looking at the calculation results in the Corrected Item-Total Correlation column. It is the same as calculating using bivariate correlation, because they both calculate the same thing. In this test, if $r_{\text {count }}$ is greater than $r_{\text {table, }}$, then the result is valid.

\section{Reliability Test}

According to (Ghozali,2018), a reliability test is a tool for measuring a questionnaire which is an indicator of a variable. The questionnaire is reliable if the respondent's response to the statement is consistent or stable over time. The statistical technique used for this test was Cronbach's Alpha coefficient. In general, the research instrument is reliable if it has a Cronbach's Alpha coefficient > 0.6. If the Cronbach's Alpha value obtained from each variable is $>0.6$, these variables are reliable.

\section{Simple Linear Regression}

Linear regression is a statistical tool and method used and processed to examine the influence of one or more variables on one variable. The variables are the management accountability of the village fund allocation variable $(\mathrm{X})$ and the detection of the community welfare variable (Y).

\section{Evaluation}


The results of this study are a description of the influence of the management accountability of village fund allocation on community welfare. Researchers obtained data from distributing questionnaires about the management accountability of village fund allocation and community welfare. The questionnaire was addressed to the people of Cibodas village, Solokan Jeruk district, Bandung regency, who are 17 years old and over. For all respondents in this study, the researchers divided them into four categories, i.e., the gender of the respondent, the age, the respondent's education level, and the occupation of the respondent. The data obtained was then processed first using statistical calculations with the help of the IBM SPSS 22 software program to be analyzed and used for hypothesis testing.

\section{Validity Test Results}

After obtaining data from the questionnaire, a validity test was conducted to test whether the questionnaire was valid or not. The provisions for making decisions are as follows:

1. If $r_{\text {count }}>r_{\text {table }}$, then the questionnaire item is valid.

2. If $r_{\text {count }}<r_{\text {table }}$, then the questionnaire item is invalid.

In this study, questionnaires were distributed to 100 respondents, with the number of statements categorized as valid has a significance level of 5\%. The number of samples is $\mathrm{n}=$ 100. Therefore, seen from the $r_{\text {table }}$ on $\mathrm{df}(\mathrm{n}-2)$, it is calculated with $\mathrm{df}=100-2=98$. Thus, $\mathrm{r}_{\text {table }}=\mathrm{r}(98,0.05)=0.165$.

To identify $\mathrm{r}_{\text {count, }}$, researchers used the assistance of IBM SPSS 22 software. The table below presents the validity test data processing results for the management accountability of the village fund allocation variable (X). The results of the validity test are as follows:

Table 1. Validity Test Results on the Variable of Village Fund Allocation Management Accountability $\left(\mathbf{X}_{1}\right)$

\begin{tabular}{clll}
\hline No. Item & r count & r table & Criteria \\
\hline 1. & 0.735 & 0.165 & Valid \\
\hline 2. & 0.803 & 0.165 & Valid \\
\hline 3. & 0826 & 0.165 & Valid \\
\hline 4. & 0.646 & 0.165 & Valid \\
\hline
\end{tabular}

Source: Data Processing Result, 2020

Based on table 1, it can be seen that in each of the questions used, the calculated $r$ value is greater than the $r$ table value (0.165). Therefore, all questions in the variable are valid.

The following is a table of the validity test data processing results for the public welfare variable (Y) using the IBM SPSS 22 software. The results of the validity test are as follows:

Table 2. Results of the Validity Test on the Public Welfare Variable (Y)

\begin{tabular}{cccc}
\hline No. Item & r count & r table & Criteria \\
\hline 1. & 0.524 & 0.165 & Valid \\
\hline 2. & 0.492 & 0.165 & Valid \\
\hline 3. & 0.464 & 0.165 & Valid \\
\hline 4. & 0.512 & 0.165 & Valid
\end{tabular}




\begin{tabular}{cccc}
5. & 0.279 & 0.165 & Valid \\
\hline 6. & 0.544 & 0.165 & Valid \\
\hline 7. & 0.577 & 0.165 & Valid \\
\hline 8. & 0.606 & 0.165 & Valid \\
\hline 9. & 0.494 & 0.165 & Valid \\
\hline 10 & 0.345 & 0.165 & Valid \\
\hline 11 & 0.422 & 0.165 & Valid
\end{tabular}

Source: Data Processing Result, 2020

Based on table 2, it can be seen that in each of the questions used, the calculated $r$ value is greater than the $r$ table value $(0.165)$. Therefore, all questions in the variable are valid.

\section{Reliability Test Results}

Based on the results of reliability testing in Table 3 , it can be seen that the $\alpha$ value of the $X_{1}$ variable is 0.798 . The Cronbach Alpha results of this variable have shown that the value is more than 0.6. Therefore, it can be concluded that the measuring instrument used to measure the variable $\mathrm{X}_{1}$ can be said as reliable.

\section{Table 3. Reliability Test Results on the Variable of Management} Accountability of Village Fund Allocation (X)

\section{Cronbach's}

\begin{tabular}{ll} 
Alpha & N of Items \\
\hline .798 & 5
\end{tabular}

Source: Data Processing Result, 2020

Based on the results of the reliability test in table 4, it can be seen that the $\alpha$ value of the $Y$ variable is 0.708 . The Cronbach Alpha results of this variable have shown that the value is more than 0.6. Therefore, it can be concluded that the measuring instrument used to measure the $\mathrm{Y}$ variable can be said as reliable.

Table 4. Reliability Test Results on the Variable of Community Welfare (Y)

\section{Cronbach's}

\begin{tabular}{ll} 
Alpha & N of Items \\
\hline .708 & 12
\end{tabular}

Source: Data Processing Result, 2020

\section{Simple Linear Regression Results}

Based on the results of the simple linear regression analysis test, the influence of accountability on the management of village fund allocations on community welfare based on IBM SPSS 22 analysis can be seen in the following Table 5:

Table 5. Simple Linear Regression Results

\section{Unstandardized Standardized

Coefficients Coefficients




\begin{tabular}{llccccc}
\hline Model & B & Std. Error & Beta & t & Sig. \\
\hline $1 \quad$ (Constant) & 15,878 & 2,101 & & 7,558 & .000 \\
\hline & $\begin{array}{l}\text { Management } \\
\text { accountability } \\
\text { of village } \\
\text { fund } \\
\text { allocation }\end{array}$ & .476 & .111 & .323 & 4,290 & .000 \\
\hline
\end{tabular}

a. Dependent Variable: Community Welfare

b. Source: Data Processing Result, 2020

The following is the formed regression model:

$\mathrm{Y}=15.878+0.476$ management accountability of village fund allocation

From the regression model, the following interpretations can be explained:

1. A constant value of 15.878 means that if the independent variable, management accountability of village fund allocation, is 0 (zero) and there is no change, then Community Welfare will be worth 15.878. In other words, the dependent variable of Community Welfare without being influenced by the independent variable already has a value of 15.878 .

2. The management accountability of village fund allocation value is 0.476 . If the management accountability of the village fund allocation variable has increased by one or better, then the Community Welfare will increase by 0.476 .

\section{Response}

Overview of Accountability and Community Welfare in Cibodas Village, Solokan Jeruk District, Bandung Regency

The study was conducted in Cibodas village, Solokan Jeruk sub-district, Bandung regency, with 100 respondents. Based on the results of the questionnaires, it is known that the resulting accountability variable (X1) is considered good. It is known that the actual score obtained from all statements that form variable $\mathrm{X}$ is 1588 , and the ideal score is 2000 with the average percentage value obtained of $79.4 \%$.

It can be seen from the four indicators that have gone well and appropriately. However, one indicator with one statement has the lowest answer. It is the indicator of supervision by the implementing team with the statement "there is supervision by the village fund allocation implementation team" with an actual score of 380 from the ideal score of $500(76 \%)$. Therefore, this percentage indicates that the village fund allocation implementation team has not fully supervised the monitoring process for the management of village fund allocations.

In the social welfare variable $(\mathrm{Y})$, it is known that the $\mathrm{Y}$ variable produced is considered good. It is known that the acute score obtained from all statements that form the variable of community welfare in Cibodas village, Solokan Jeruk district, Bandung regency is 4081 and the ideal score is 5500 with a percentage value obtained of $74.2 \%$.

However, one indicator is divided into four statements with the lowest answer. It is the indicator of economic justice with the statement "Village fund allocation can improve community welfare," with an actual score of 353 from the ideal score of 500 (70.6\%). Therefore, this percentage indicates that the Village fund allocation in Cibodas village, Solokan Jeruk district, Bandung regency has not fully improved the economic welfare of the entire community. 


\section{The Influence of ADD Management Accountability on Community Welfare in Cibodas Village}

Based on the results of the performed analysis, it shows that accountability in the village fund allocation management influences community welfare. The results of the hypothesis testing for the management accountability of village fund allocation for community welfare in table 5 partially show a significance value of 0.000 . Based on these results, a significant value $<0.05$ means that the management accountability of village fund allocation has a partially significant influence on the community welfare in Cibodas village.

This study provides evidence that the management accountability of village fund allocation partially influences the community welfare, where the village government is accountable in managing village fund allocations. This effort is shown by installing financial banners published in front of the village office or published through village-owned official social media account as an effort to be accountable to the village community regarding village finances.

Following (Yuliansyah and Rusmianto 2015), transparent and accountable management of village fund allocations can help improve rural communities' welfare and quality of human life. The results of this study are also in line with (Dura,2016), (Widya et al.,2017), (Lasa et al.,2018), (Aprilia,2019), (Nur and Fitri, 2019), (Dalipang et al., 2019), (Rosiana Dewi and Sapari,2020), (Manik et al., 2020), and (Ilmiah et al., 2020) who in their studies state that the management accountability of village fund allocation has a significant influence on the welfare of village communities.

\section{Conclusion}

Based on the results of this study and described discussions above, the researchers draw the following conclusions: Accountability for the management of Village fund allocation and community welfare in Cibodas village, Solokan Jeruk district, Bandung regency as a whole is good, especially in reporting the management accountability of village fund allocation. It shows that the village government has fulfilled its responsibilities to the community for managing village fund allocations. The implementation of accountability to the community is carried out with the installation of financial banners published in front of the village office and published through the village's official social media account. This study shows that the variable of management accountability of village fund allocation (X) has a significant influence on the community welfare (Y) in Cibodas village, Solokan Jeruk district, Bandung regency.

\section{References}

Aprilia, I. (2019). Determinants of Accountability and Transparency of Village Fund Allocation Management and Its Impact on Community Trust. Akurasi: Jurnal Studi Akuntansi dan Keuangan, 2(2), 109-122. (Translate from Indonesian: Determinan Akuntabilitas Dan Transparansi Pengelolaan Alokasi Dana Desa dan Dampaknya Terhadap Kepercayaan Masyarakat. Akurasi: Jurnal Studi Akuntansi dan Keuangan, 2(2), 109-122).

Dura, J. (2016). The Effect of Financial Management Accountability of Village Fund Allocations, Village Policies, and Village Institutions on Community Welfare. Jurnal Ilmiah Bisnis dan Ekonomi Asia, 10(2), 26-32. (Translate from Indonesian: Pengaruh akuntabilitas pengelolaan keuangan alokasi dana desa, kebijakan desa, dan kelembagaan desa terhadap kesejahteraan masyarakat. Jurnal Ilmiah Bisnis dan Ekonomi Asia, 10(2), 26-32). 
Dewi, F. G. R. (2020). The Effect of Village Fund Allocation Accountability, Transparency, Village Policy, Community Participation on Development. Jurnal Ilmu dan Riset Akuntansi (JIRA), 9(5). (Translate from Indonesian: PENGARUH AKUNTABILITAS ALOKASI DANA DESA, TRANSPARANSI, KEBIJAKAN DESA, PARTISIPASI MASYARAKAT TERHADAP PEMBANGUNAN. Jurnal Ilmu dan Riset Akuntansi (JIRA), 9(5))

Ghozali, I. (2018). Applications of Multivariate Analysis With IBM SPSS 25 Program (Translate from Indonesian: Aplikasi Analisis Multivariate Dengan Program IBM SPSS 25.

Mahmudi. (2016). Public Sector Accounting Revised Edition. Yogyakarta: UII Press. (Translate from Indonesian: Akuntansi Sektor Publik Edisi Revisi). Yogyakarta: UII Press.

Dalipang, M. I., Kalangi, L., \& Kalalo, M. Y. (2019). Evaluation of Accountability and Transparency of Village Fund Allocation Management (ADD) in Sea Satu Village, CHT Housing, Minahasa Regency. Jurnal EMBA: Jurnal Riset Ekonomi, Manajemen, Bisnis dan Akuntansi,7(4). (Translate from Indonesian: EVALUASI AKUNTABILITAS DAN TRANSPARANSI PENGELOLAAN ALOKASI DANA DESA (ADD) DI DESA SEA SATU PERUMAHAN CHT, KABUPATEN MINAHASA. Jurnal EMBA: Jurnal Riset Ekonomi, Manajemen, Bisnis dan Akuntansi, 7(4)).

Mardiasmo, D., \& MBA, A. (2009). Public sector accounting. Yogyakarta: Andi. (Translate from Indonesian: Akuntansi Sektor Publik. Yogyakarta: Andi).

Manik, O. J., et.al. (2020). The Effect of Village Fund Allocation Management on the Welfare of the People of Nagori Negeri Dolok, Dolok Panribuan District, Simalungun Regency. Jurnal Regional Planning, 9(1), 15-33. (Translate from Indonesian: Pengaruh Pengelolaan Alokasi Dana Desa Terhadap Kesejahteraan Masyarakat Nagori Negeri Dolok Kecamatan Dolok Panribuan Kabupaten Simalungun). Jurnal Regional Planning, 9(1), 15-33.

Regulation of the Minister of Home Affairs of the Republic of Indonesia Number 114 of 2014 concerning Village Development Guidelines (Translate from Indonesian: Peraturan Menteri Dalam Negeri Republik Indonesia Nomor 114 Tahun 2014 tentang Pedoman Pembangunan Desa).

Government Regulation Number 60 of 2014 concerning Village Funds Sourced from the State Revenue and Expenditure Budget (Translate from Indonesian: Peraturan Pemerintah Nomor 60 Tahun 2014 tentang Dana Desa Yang Bersumber Dari Anggaran Pendapatan Dan Belanja Negara).

Minister of Home Affairs Regulation Number 20 of 2018 concerning Village Financial Management (Translate from Indonesian: Peraturan Menteri Dalam Negeri Nomor 20 Tahun 2018 tentang Pengelolaan Keuangan Desa).

Wida, S. A., Supatmoko, D., \& Kurrohman, T. (2017). Management accountability of village fund allocation (ADD) in the Villages of Rogojampi District, Banyuwangi Regency. E-Journal Ekonomi Bisnis Dan Akuntansi, 4(2), 148-152. (Translate from Indonesian: Akuntabilitas Pengelolaan Alokasi Dana Desa (ADD) di Desa-Desa Kecamatan Rogojampi Kabupaten Banyuwangi. E-Journal Ekonomi Bisnis Dan Akuntansi, 4(2), 148-152).

Nur, S. W., \& Fitri, F.. (2019). Increasing Transparency, Accountability, and Participation through Village Fund Allocation Management in Tellumpanuae Village, Maros Regency. Jurnal Dedikasi Masyarakat,3(1), 1-9. (Translate from Indonesian: Peningkatan transparansi, akuntabilitas, dan partisipatif melalui pengelolaan alokasi 
dana desa di desa tellumpanuae kabupaten maros. Jurnal Dedikasi Masyarakat, 3(1), $1-9)$.

Law Number 11 of 2009 concerning Social Welfare (Translate from Indonesian: Undangundang Nomor 11 Tahun 2009 tentang Kesejahteraan Sosial).

Lasa, Y. A., \& Lestari, A. W. (2019). Management of Accountability and Transparency in the Management of Village Fund Allocation (ADD) on Village Community Participation. JISIP: Jurnal Ilmu Sosial dan Ilmu Politik,7(1). (Translate from Indonesian: Pengaruh Akuntabilitas dan Transparansi Pengelolaan Alokasi Dana Desa (ADD) terhadap Partisipasi Masyarakat Desa. JISIP: Jurnal Ilmu Sosial dan Ilmu Politik, 7(1).

Desa, A., \& Yuliansyah, R. (2015). Village Accounting. Jakarta: Salemba Empat. (Translate from Indonesian: Akuntansi Desa. Jakarta: Salemba Empat). 